\title{
RELATIONS BETWEEN INCOME INEQUALITY, ECONOMIC GROWTH AND POVERTY THRESHOLD: NEW EVIDENCES FROM EU COUNTRIES PANELS ${ }^{\#}$
}

\author{
Georgeta SOAVA (iD $1^{*}$, Anca MEHEDINTU ${ }^{(1)}$, Mihaela STERPU ${ }^{2}$ \\ ${ }^{1}$ Department of Statistics and Economic Informatics, Faculty of Economics and Business Administration, \\ University of Craiova, Craiova, Romania \\ ${ }^{2}$ Department of Mathematics, Faculty of Sciences, University of Craiova, Craiova, Romania
}

Received 26 November 2018; accepted 15 September 2019

\begin{abstract}
This paper analyses the relationship between the following indicators: income inequality, gross domestic product, risk of poverty threshold and median equivalized net income for a panel of 28 countries of European Union (EU) over the period 2005-2016. Two theoretical regression models, a linear and a quadratic one, are used to estimate the influence on income inequality of the other three indicators. Empirical estimations, using panel data techniques on three different data panels, confirm the Kuznets hypothesis that income inequality tends to increase with early economic development and tends to decrease when a country reaches a certain level of development. We found that for emerging EU countries, income inequality has a growing tendency with a positive economic growth and maybe reduced by increasing risk of poverty threshold or median equivalized net income. For highly developed EU countries the situation is completely opposite. At EU level, the influence of gross domestic product on income inequality is strongly determined by its trend in the highly developed EU countries, while the influence of risk of poverty threshold and median equivalized net income on income inequality is strongly determined by their trend in the emerging EU countries.
\end{abstract}

Keywords: income inequality, GINI index, economic growth, risk of poverty threshold, data panel, regression model, Kuznets hypothesis, European Union.

JEL Classification: C13, C23, O11.

\section{Introduction}

Globalization and new inventions have transformed the economy of the whole world, and especially of European countries, and although economic growth has started to boom throughout the world, inequalities between the rich and the poor have deepened further. Thus, a

\footnotetext{
\# The results in this paper were partially presented at the International Conference "Information Society and Sustainable Development" - ISSD 2018, 5th edition, April 27-28, 2018, Faculty of Economics, "Constantin Brancusi" University of Targu-Jiu, Romania.
}

${ }^{\star}$ Corresponding author. E-mail: georgetasoava@yahoo.ro 
progressive strategy was needed to reduce disparities without undermining economic growth (European Commission, 2017; World Bank, 2001).

One of the priorities of the Europe 2020 strategy is inclusive growth which includes, among other things, guaranteeing everyone access to the benefits of economic growth. In this respect, the EU has placed combating poverty and social exclusion as one of the core objectives of the Europe 2020 strategy, poverty reduction being an essential element of economic growth. One of the major innovations of the Europe 2020 strategy for smart, sustainable and inclusive growth was to set a new common target in combating poverty and social exclusion, namely to reduce the number of Europeans living below the national poverty line by $25 \%$. Thus, one of the initiatives was to develop a European platform against poverty and reduce the number of people suffering from or at risk of suffering from poverty and social exclusion by at least 20 million (European Commission, 2017).

As an increasing number of persons were exposed to poverty risk, due to the economic crisis at the beginning of the 21th century, the European Commission proposed a new command line to monitor and mitigate economic disparities between states, whereby member states have to allocate at least $20 \%$ of the financial envelopes under the European Social Fund (European Union, 2013), in order to promote social inclusion and fight against poverty. European Anti-Poverty Network (2016), the largest platform of anti-poverty organizations in Europe, has called into question the "unacceptable levels of poverty and social exclusion in the EU, with which are confronted by nearly $25 \%$ of the population", to achieve the Europe 2020 objectives, in particular the poverty target.

Comparison of living standards across countries is most often based on per capita gross domestic product (GDP) expressed in monetary terms. There are large differences between EU countries despite convergence efforts (Strielkowski \& Höschle, 2016). However, this indicator reflects very little of the income distribution issues within the country and, at the same time, does not provide information on non-monetary factors, which may play a significant role in determining the quality of life of a particular population (Soava, Mehedintu, Sterpu, \& Raduteanu, 2018). Inequalities in income distribution can either create incentives to improve the quality of life or could be the premises of poverty and social exclusion.

An economic tool to measure income inequality is the Lorenz Curve. The graph plots the percentage of the total income of the population that is earned by the bottom $\mathrm{x} \%$ of the population. The Gini coefficient, defined based on the Lorentz Curve, can be used as a quantitative indicator that reflects the degree of inequality of the various incomes distribution options (Ceriani \& Verme, 2012). A less equal distribution of income causes as the Gini coefficient to be closer to 1 ( 1 corresponds to absolute inequality). Thus, the more uniform the distribution, the GINI coefficient will be closer to zero (zero corresponds to absolute equality).

The relationship between income inequality, economic growth and poverty has been studied by many researchers, on different countries and groups of countries, different period of time, or different types of economic development stages, without finding universally valid conclusions.

Many researchers have explored the role of economic growth in combating poverty and income inequality, and they appreciate that the association of incomes with inequalities (measured by the Gini index) and the poverty threshold could be positive or negative, depending on the level of wealth of countries (Fosu, 2017; Brady \& Jäntti, 2017; Edward 
\& Sumner, 2018). Inequality and poverty influence each other both directly and indirectly through their connection with economic growth. The current model underlying the study of poverty in both developing and developed countries is the model of the Bourguignon triangle (2003), the Poverty-Growth-Inequality Triangle, where inequality and growth influence each other and both influence poverty.

In this context, the overall objective of this study is to determine for EU member countries the impact of economic growth, median equivalized net income (MENI) and the risk of poverty threshold (RPT) on income inequalities for EU countries. For this purpose, we collected the information provided by Eurostat for the period 2005-2016 for the $28 \mathrm{EU}$ member states. The analysis of these data series is performed using the econometric software package EViews 9 (2015).

The study of this configuration of economic indicators, the time period and groups of countries cannot be found in other similar works.

The research is conducted in two directions. Firstly, we analyzed the four indicators (Gini index, per capita gross domestic product, per capita risk of poverty threshold, and median equivalized net income) and their tendencies over the period 2005-2016, by means of usual statistic descriptors. The large variations in the values of the analyzed indicators from one country to another led us to consider beside the EU28 panel, two additional data panels, corresponding to 11 highly developed EU countries and 9 emerging EU countries, respectively. Secondly, we investigated empirically the influence on the income inequality of the other three indicators using two regression models (a linear and a quadratic one). To this aim, panel cointegration techniques are applied on these three different panels. Finally, the empirical results are interpreted from economic point of view, and compared with results obtained in similar studies, where available.

So, using the linear model, for both EU28 and emerging countries panels, we found that a decrease on income inequality can be obtained by increasing RPT or MENI, while the increase of income inequality is determined by the growth of GDP. For the highly developed EU countries panel an opposite behavior was found, namely an increasing GDP leads to a decrease of income inequality, while RPT and MENI have a direct influence on income inequality.

Using the quadratic model, we found that MENI and RPT have a negative influence on income inequality for both EU28 and emerging countries panels, yet a positive influence for the highly developed EU countries panel, as in the linear case. In addition, we obtained that the influence of GDP on income inequality follows a " $U$ "-shaped form for both EU28 and highly developed EU countries panels, and for emerging countries an inverted U-shape.

The main conclusion and novelty of this study concerns the influence of the investigated indicators on income inequality, and it is derived by the use of two data panels corresponding to highly developed EU countries and emerging EU countries. Thus, for the emerging EU countries positive economic growth leads to increase income inequality, while increasing risk of poverty threshold or median equivalized net income tends to diminish the income inequality. For highly developed EU countries, economic growth leads to a decrease in income inequality, while increasing risk of poverty threshold or median equivalized net income leads to increase income inequality. 
We find that at EU level, the influence of gross domestic product on income inequality is strongly determined by its trend in the highly developed EU countries, while the influence of risk of poverty threshold and median equivalized net income on income inequality is strongly determined by their trend in the emerging EU countries.

Concerning the economic policy measures at EU level, the empirical results obtained in the paper suggest that these measures should be differentiated taking into account the country's individual characteristics as well as the expected horizons in response.

This paper is organized as follows. Section 1 contains a brief review of literature on empirical studies on the analyzed indicators, while the background of research (data, models, methodology) are described in Section 2. Section 3 presents an analysis of the evolutions of the indicators, the empirical investigations of the two regression models and results. The last section concludes the study.

\section{Literature review}

The relationship between economic growth and income inequality has been studied by economists for more than a century. However, the problem remains in study and it is very important to address the extent to which income inequality affects the economic growth of a country, respectively finding the answer to the question weather the economic growth effectively contributes to reduce relative poverty and income inequality or it can exacerbate existing income inequalities?

The role and influence of income distribution on economic growth has been brought to attention by numerous authors who have produced some empirical evidence of the effects of inequality on economic growth. Income inequality reentered into the attention of development policy (World Bank, 2001).

The Gini coefficient determines the extent to which the distribution of income among individuals (households) in a country's economy deviates from a perfectly equal distribution. The Gini coefficient varies from one country to another and, for the same country, over time. The higher its value, the disposable income of the population is distributed more unequally (OECD, 2014).

GDP is the most commonly used macroeconomic indicator for the global assessment of an economy. Nominal GDP is commonly used to determine the economic performance of an entire country or region and to make international comparisons. GDP per capita is used to eliminate the influence of the absolute size of the population, allowing easier comparison of living standards between different countries.

The relationship between income inequality and economic growth has been analyzed at both aggregate and regional levels, for different groups of countries, for longer or smaller time periods: 28 EU countries (Zagorski, Evans, Kelley, \& Piotrowska, 2014), OECD countries (Cingano, 2014), a panel of 81 countries (23 developed and 58 developing countries) between 1990-2010 (Chambers \& Dhongde, 2016).

Studies on the effect of inequality on economic growth have found that it may be positive or negative depending on the different phases of development (Inyong, 2012; Binatli, 2012), and it may also be influenced by variations in the level of development, policies and 
institutions (Chang, Gupta, \& Miller, 2018; Rubin \& Segal, 2015; Luan \& Zhou, 2017). In poor countries, increasing income inequality leads to GDP per capita growth, while for rich countries the situation is reversed (Brueckner, Dabla Norris, \& Gradstein, 2015).

According to Kuznets (1955), the increase of income inequality may correspond to an increase in the level of development of a country, being specific to the beginning of any economy, but once the economy reaches a certain stage of development, the income inequality decreases. The results of various studies show that change in income inequality does not have the same effect in all countries (Baiardi \& Morana, 2016, 2018; Grijalva, 2011).

Analysis of the influence of income inequality on the economic growth of a country have been made taking into account a number of other factors, such as additional foreign direct investment and export indicators (Halmos, 2011), or financial development (Jauch \& Watzka, 2016).

The poverty threshold, used to determine poverty, refers to the level of economic resources (expressed in money) needed to ensure the acceptable considered lifestyle. Establishing the poverty threshold is a problem (Chang et al., 2018). There are two types of poverty: relative poverty, when income is lower than average income by a certain percentage, and absolute poverty, when income is below the minimum necessary to ensure a minimum standard of living.

Relative poverty is a concept very similar to income inequality (relative poverty focuses on the bottom of income distribution and income inequality takes into account the entire population). Darvas (2019) proved that the "poverty risk or social exclusion" indicator set out in the Europe 2020 strategy mainly measures income inequality or relative poverty.

For poverty indicators, the adult-equivalent disposable income is calculated by dividing the household's total disposable income, by the adult-equivalent size of the household.

Inequality and poverty influence each other both directly and indirectly through their connection with economic growth. Poverty can be reduced by revenue growth, by changes in income distribution or by a combination of the two, through certain social policies (Laurinavičius \& Galinienè, 2013). Thus, many researchers have explored the role of economic growth in poverty and income inequality (Ben Amar \& Zghidi, 2016; Brady \& Jäntti, 2017; Chemli \& Smida, 2013; Edward \& Sumner, 2018; Fosu, 2017; Škare \& Pržiklas Družeta, 2016).

Mihi-Ramírez, Kumpikaitè-Valiūnienè, and Cuenca-García (2017) appreciate that the association of incomes with inequalities (measured by the Gini index) and the poverty threshold could be positive or negative, depending on the level of wealth of countries.

Hillebrand (2009) analyzed the evolution of economic growth, poverty rate and income inequality over the period 1981-2005 globally, and made a forecast of these indicators by 2050 based on two different scenarios of global economic growth.

Poverty, inequality and growth can interact with each other through a set of bidirectional links. Bourguignon (2003) analyzed the interactions between poverty, inequality (Gini index) and growth (per capita income) and created the Poverty-Growth-Inequality Triangle (GIP Triangle) for developed countries, where inequality and growth influence each other and both influence absolute poverty, and based on this model, economists working for international organizations have studied poverty both in developing countries and in developed countries. 


\section{Data, models, methodology}

\subsection{Data source}

Macroeconomic indicators used, covers the period 2005-2016 and have as source the Eurostat database:

- GINI - the Gini index, expressed as a percentage;

- GDP - gross domestic product per capita, in Euro;

- RPT - per capita risk of poverty threshold, in Euro;

- MENI - median equivalized net income, in Euro.

By combining the two dimensions, the data series for the indicators are organized as panels. The values of the last three indicators are considered in logarithmic form, the corresponding variables being denoted as LGDP, LMENI, LRPT.

\subsection{Models used}

In this study we aim to determine the relationship between GINI and GDP and also the effect of poverty threshold or median equivalized net income on this index, through by two models. We use GINI index as a dependent variable, while per capita LGDP, and LRPT or LMENI are considered independent variables.

Model 1 verify the relationship between the Gini index and the gross domestic product and also the effect of poverty threshold on this index is the linear model

$$
Y_{i t}=\alpha_{0}+\alpha_{1} X_{i t}+\alpha_{2} Z_{i t}+u_{i t},
$$

where: $Y$ - the GINI index; $X$ - per capita LGDP; $Z$ - the explanatory variable (LRPT or LMENI); $u_{i t}$ - the error term, $i$ - the countries, and $t$ - time.

Model 2. The second model tests the inverse U-shaped Kuznets form (EKC) hypothesis, using the quadratic equation

$$
Y_{i t}=\beta_{0}+\beta_{1} X_{i t}+\beta_{2} X_{i t}^{2}+\beta_{3} Z_{i t}+u_{i t}
$$

The variables have the same meaning as in model 1 . As explanatory variable we consider either LRPT or LMENI, as above, or none of them.

In the quadratic case (2), the shape of the graph is given by the signs of the coefficients $X$, $X^{2}$ or the relationship between them. In this way, the graph is $U$-inverted shaped if $\beta_{2}<0$ for the relationship between GINI and LGDP. The value of the turning point for $X\left(x_{0}=-\frac{\beta_{1}}{2 \beta_{2}}\right)$ is positive when $\beta_{1}>0$, and the fixed values of $Z$ variables correspond to the maximum value of the $Y$.

\subsection{Methodology}

The values of the 4 macroeconomic indicators, for all EU states, for the 12 years, have been econometrical analyzed (mean value, standard deviation, kurtosis etc.). 
As the data contain information only on 12 years span, the individual time series do not allow to derive statistically significant results. Thus, we opted for the panel cointegration approach.

As there are differences between GDP per capita for the countries in the panel, we also constructed two other partial data panels. Thus, in panel 1 we included data for 11 countries with GDP per capita superior to the EU mean. Panel 2 includes data for 9 countries with the lowest GDP that are also emerging countries.

We applied models 1 and 2 using the panel technique for three data panels. We first analyzed whether the data are stationary using LLC unit root test (Levin, Lin, \& Chu, 2002), ADF-Fisher and PP-Fisher tests (Choi, 2001), and then we tested the existence of a cointegration relationship between the variables, using Kao (1990) and Pedroni (Pedroni, 1999) tests. Next, as the variables are cointegrated, we used panel Least Square for determining the coefficients of the regression equation. We performed the Hausman test and the one with redundant fixed effects to choose the most suitable effect of the data.

Finally, the Granger causality test (Engle \& Granger, 1987) is used to find causalities between the variables.

For data processing and analysis we used EViews 9 software (2015).

\section{Results}

\subsection{Data analysis}

The values of the GINI index of income inequality for the 28 countries of EU (Austria-AT, Belgium-BE, Bulgaria-BG, Croatia-HR, Cyprus-CY, Czech Republic-CZ, Denmark-DK, Estonia-EE, Finland-FI, France-FR, Germany-GE, Greece-EL, Hungary-HU, Ireland-IE, Italy-IT, Latvia-LV, Lithuania-LT, Luxembourg-LU, Malta-MT, Netherlands-NL, Poland-PL, Portugal-PT, Romania-RO, Slovakia-SK, Slovenia-SI, Spain-ES, Sweden-SE, United Kingdom-UK), show that it varies from one country to another, but also in the same country over time.

The value of the GINI index in 2016 compared to the first year of the analyzed period recorded a slight decrease for 12 of the 28 EU countries (Figure 1). Note that for Bulgaria, Croatia and Romania the first available data (concerning GINI, MENI and RPT) are recorded in 2006, 2010, 2007, respectively. Poland recorded the largest decline (16.29\%) of GINI index compared to 2005, while Bulgaria the largest increase (20.83\%), followed closely by Sweden, Luxembourg, Denmark and Germany.

The indicator of country average income is GDP at purchasing power parity. As a result of the analysis, we see that states registering a lower GDP usually have a higher income inequality. Regarding the RPT and MENI indicators, we note that they have a similar evolution. Thus, countries with high income inequality indicators also have a poverty line or a very low average income. In Figure 2 we plotted the relative rate of growth of the three indicators in 2016 with respect to 2005. Thus, Romania has the highest rate of growth of GDP in 2016 relative to 2005, while reporting the lowest poverty threshold overall EU in 2016. 


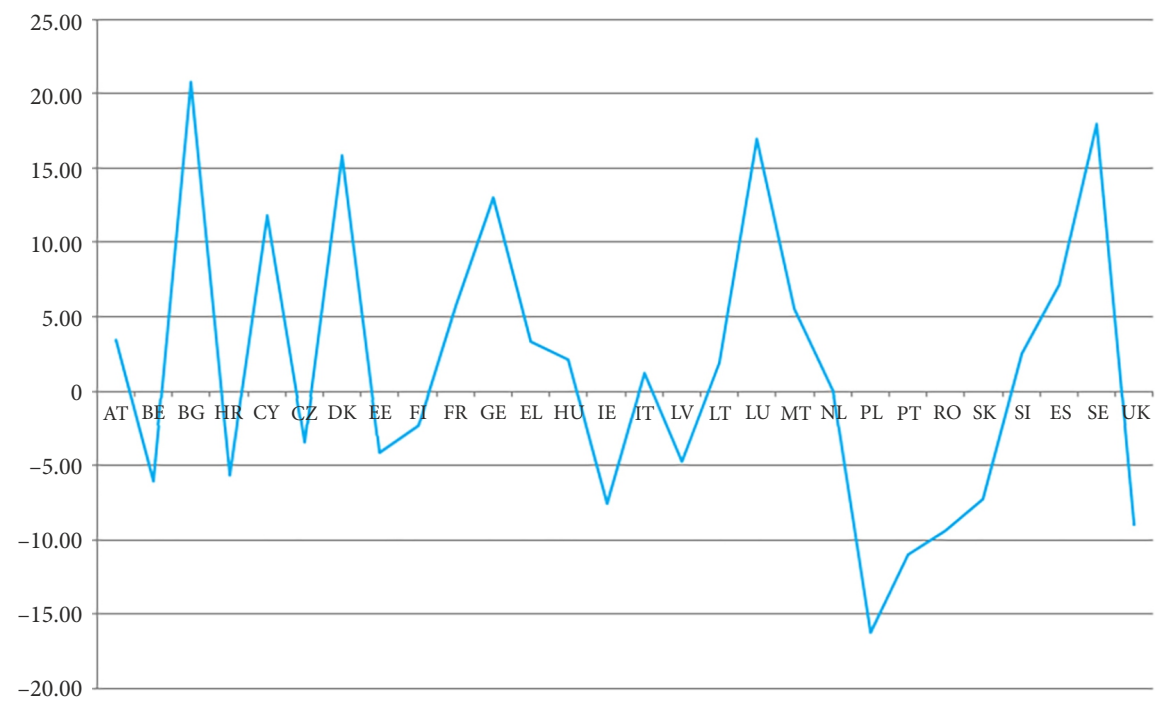

Figure 1. GINI evolution in EU member countries in 2016/2005

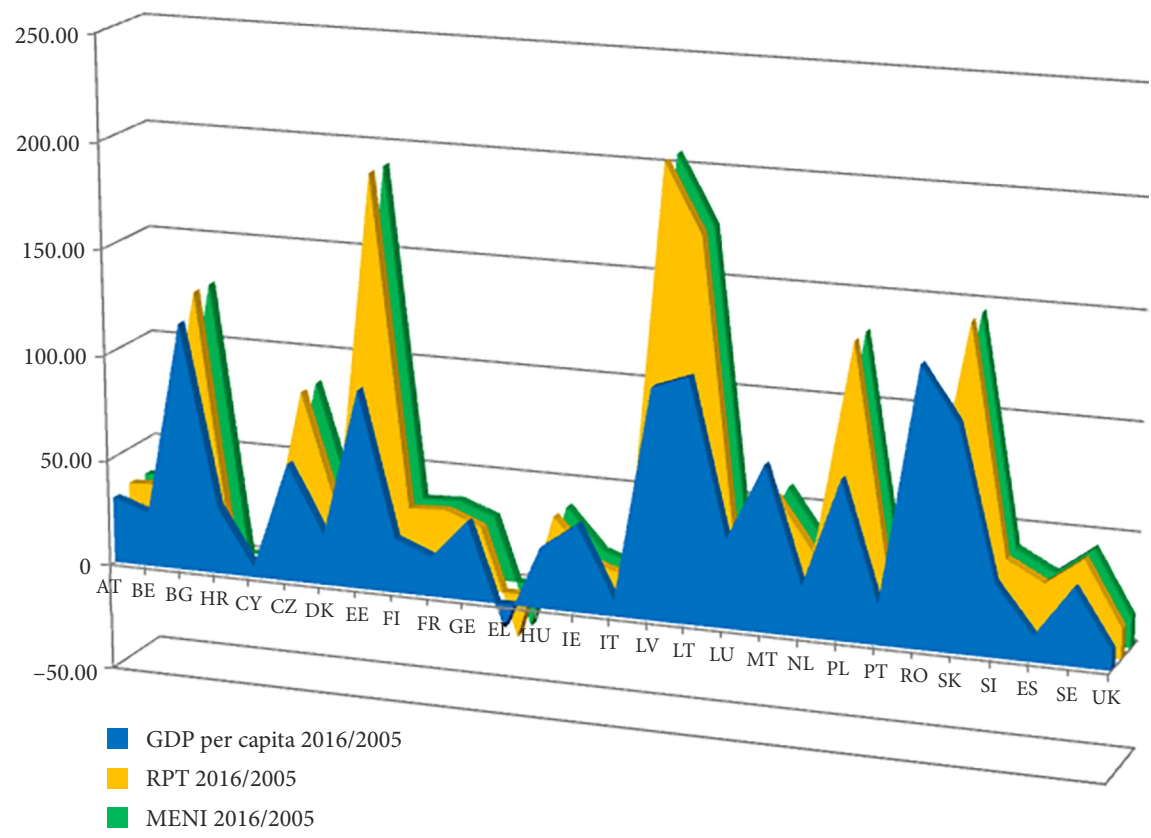

Figure 2. Evolution of GDP, RPT and MENI in 2016/2005, for EU member countries

In Table 1 we present the descriptive statistics for the analyzed indicators for each country. Most countries have a platykurtic distribution, with a left asymmetry across all the indicators studied. Concerning the GINI index, Austria, Germany and United Kingdom have a distribution close to the normal one, while Czech Republic and Hungary have a leptokurtic 
distribution, the other countries have a platykurtic distribution; the distributions for $16 \mathrm{EU}$ countries have a slight left asymmetry (except Greece, Hungary and Poland with a pronounced asymmetry), the others have a slight right asymmetry. The GDP has: an almost normal distribution for Italy, Portugal and Romania; a slightly leptokurtic for the Czech Republic, Croatia, Ireland, Netherlands and Slovenia; while for all others a platykurtic distribution; with asymmetry to the left in 21 countries.

The RPT indicator shows an almost normal distribution for Hungary and Italy, and a leptokurtic one for Romania. MENI has a platykurtic distribution for all countries, except for Spain with a normal distribution and Netherland having a leptokurtic distribution and a pronounced right asymmetry. Both indicators show a slight asymmetry to the left for almost half of the countries.

Table 1. Descriptive statistics for GINI, GDP, RPT, MENI for 28 EU countries, period 2005-2016

\begin{tabular}{|c|c|c|c|c|c|c|c|c|c|c|c|c|}
\hline & \multicolumn{3}{|c|}{ GINI } & \multicolumn{3}{|c|}{ GDP } & \multicolumn{3}{|c|}{ RPT } & \multicolumn{3}{|c|}{ MENI } \\
\hline & Mean & Kurtosis & Skew-ness & Mean & Kurtosis & Skew-ness & Mean & Kurtosis & Skew-ness & Mean & Kurtosis & Skew-ness \\
\hline AT & 0.271 & 3.199 & 0.989 & 36349 & 2.035 & -0.227 & 12511 & 1.719 & 0.082 & 22367 & 1.448 & 0.081 \\
\hline $\mathrm{BE}$ & 0.266 & 2.420 & -0.163 & 33926 & 2.245 & -0.262 & 11777 & 1.680 & -0.266 & 20984 & 1.559 & -0.266 \\
\hline BG & 0.348 & 2.592 & 0.130 & 5172 & 2.468 & -0.585 & 1602 & 2.607 & 0.353 & 3073 & 1.505 & 0.354 \\
\hline HR & 0.307 & 1.941 & -0.024 & 10251 & 4.214 & -1.217 & 3278 & 1.816 & -0.107 & 5464 & 1.815 & -0.108 \\
\hline CY & 0.308 & 2.299 & 0.101 & 22255 & 1.577 & 0.082 & 9218 & 1.684 & -0.103 & 15455 & 1.330 & -0.103 \\
\hline CZ & 0.251 & 4.597 & -0.834 & 14567 & 3.306 & -1.080 & 4035 & 2.334 & -0.792 & 7554 & 2.627 & -0.793 \\
\hline DK & 0.262 & 2.182 & 0.205 & 44500 & 2.186 & -0.195 & 15473 & 1.671 & -0.566 & 27447 & 2.547 & -0.566 \\
\hline $\mathrm{EE}$ & 0.329 & 2.290 & 0.616 & 12609 & 2.083 & -0.190 & 3523 & 2.412 & 0.460 & 6806 & 1.804 & 0.459 \\
\hline FI & 0.258 & 1.865 & 0.344 & 35958 & 2.416 & -0.547 & 12775 & 1.757 & -0.634 & 22894 & 1.806 & -0.634 \\
\hline FR & 0.292 & 2.455 & 0.318 & 31248 & 2.395 & -0.490 & 11647 & 2.007 & -0.178 & 20830 & 1.644 & -0.178 \\
\hline GE & 0.291 & 3.022 & -0.083 & 32945 & 1.753 & 0.138 & 11271 & 2.634 & 0.594 & 19813 & 2.157 & 0.594 \\
\hline EL & 0.339 & 1.506 & -1.135 & 18640 & 1.480 & 0.192 & 5765 & 1.723 & 0.624 & 9076 & 1.816 & 0.624 \\
\hline $\mathrm{HU}$ & 0.273 & 4.176 & -1.442 & 10186 & 2.190 & 0.134 & 2604 & 2.978 & -0.258 & 4531 & 2.470 & -0.251 \\
\hline IE & 0.305 & 2.084 & -0.096 & 43218 & 3.325 & 1.277 & 12508 & 1.594 & 0.870 & 20587 & 2.164 & 0.869 \\
\hline IT & 0.323 & 2.622 & -0.397 & 27071 & 3.094 & -0.697 & 9336 & 2.995 & 0.682 & 15928 & 2.706 & 0.678 \\
\hline LV & 0.361 & 3.109 & 0.602 & 10066 & 2.327 & -0.554 & 2663 & 2.476 & 0.662 & 5028 & 1.971 & 0.662 \\
\hline LT & 0.352 & 2.220 & -0.227 & 10150 & 1.967 & -0.173 & 2463 & 2.536 & 0.247 & 4653 & 1.932 & 0.247 \\
\hline LU & 0.284 & 2.770 & -0.640 & 81622 & 2.326 & -0.373 & 19241 & 2.134 & 0.554 & 33480 & 2.080 & 0.554 \\
\hline MT & 0.276 & 2.206 & -0.108 & 16829 & 2.208 & 0.576 & 6606 & 1.829 & -0.050 & 12099 & 1.527 & -0.050 \\
\hline NL & 0.264 & 1.767 & 0.274 & 38602 & 3.447 & -0.878 & 11955 & 2.500 & 1.369 & 20988 & 3.701 & 1.369 \\
\hline PL & 0.316 & 4.774 & -1.315 & 9438 & 2.224 & -0.608 & 2741 & 2.309 & -0.287 & 5204 & 2.660 & -0.286 \\
\hline PT & 0.352 & 2.216 & -0.085 & 16576 & 2.981 & -0.167 & 4877 & 2.393 & 0.480 & 8433 & 1.890 & 0.483 \\
\hline RO & 0.351 & 2.634 & 1.263 & 6536 & 2.869 & -0.569 & 1250 & 3.572 & 0.896 & 2159 & 2.297 & 0.896 \\
\hline SK & 0.252 & 3.141 & -0.228 & 12232 & 2.780 & -0.939 & 3368 & 2.075 & -0.875 & 6682 & 2.084 & -0.874 \\
\hline SI & 0.239 & 2.586 & 0.302 & 17672 & 3.532 & -0.964 & 6753 & 2.479 & 0.183 & 12040 & 1.645 & 0.181 \\
\hline ES & 0.334 & 1.498 & -0.277 & 23026 & 2.011 & -0.038 & 7911 & 2.549 & 0.893 & 13747 & 2.916 & 0.896 \\
\hline SE & 0.256 & 2.108 & 0.537 & 41135 & 1.684 & -0.258 & 13053 & 1.393 & -1.062 & 23720 & 2.661 & -1.063 \\
\hline UK & 0.324 & 2.818 & -0.319 & 33645 & 2.354 & 0.110 & 11458 & 1.894 & -0.192 & 19256 & 1.483 & -0.191 \\
\hline EU & 0.307 & 1.333 & 0.042 & 26352 & 2.350 & 0.202 & 8032 & 2.036 & -0.418 & 15592 & 1.898 & 0.246 \\
\hline
\end{tabular}


Ranking EU countries descending according to mean GDP, it is obvious that the economy of the countries at the bottom of the ranking is much smaller and their citizens can not enjoy the same quality of life as those living in the countries at the top. Most states that joined EU in 2004, 2007 or 2013, evolved from values of GDP way below the $2006 \mathrm{EU}$ average to values closer to the $2016 \mathrm{EU}$ average, despite the shortcomings created by the global crisis.

Analyzing the average of each country's indicators compared to the EU level, it is noticed that 12 of them are situated above the EU level, while 16 below the EU average, except for RPT, for which 15 are below the EU average (Figure 3). All countries have the same positions above or below the EU mean, for all three indicators, except for Cyprus, for which the RPT mean is above the EU level, while the other two mean values are situated below the corresponding EU mean. The only element changing from one indicator to the other is the relative ranking.

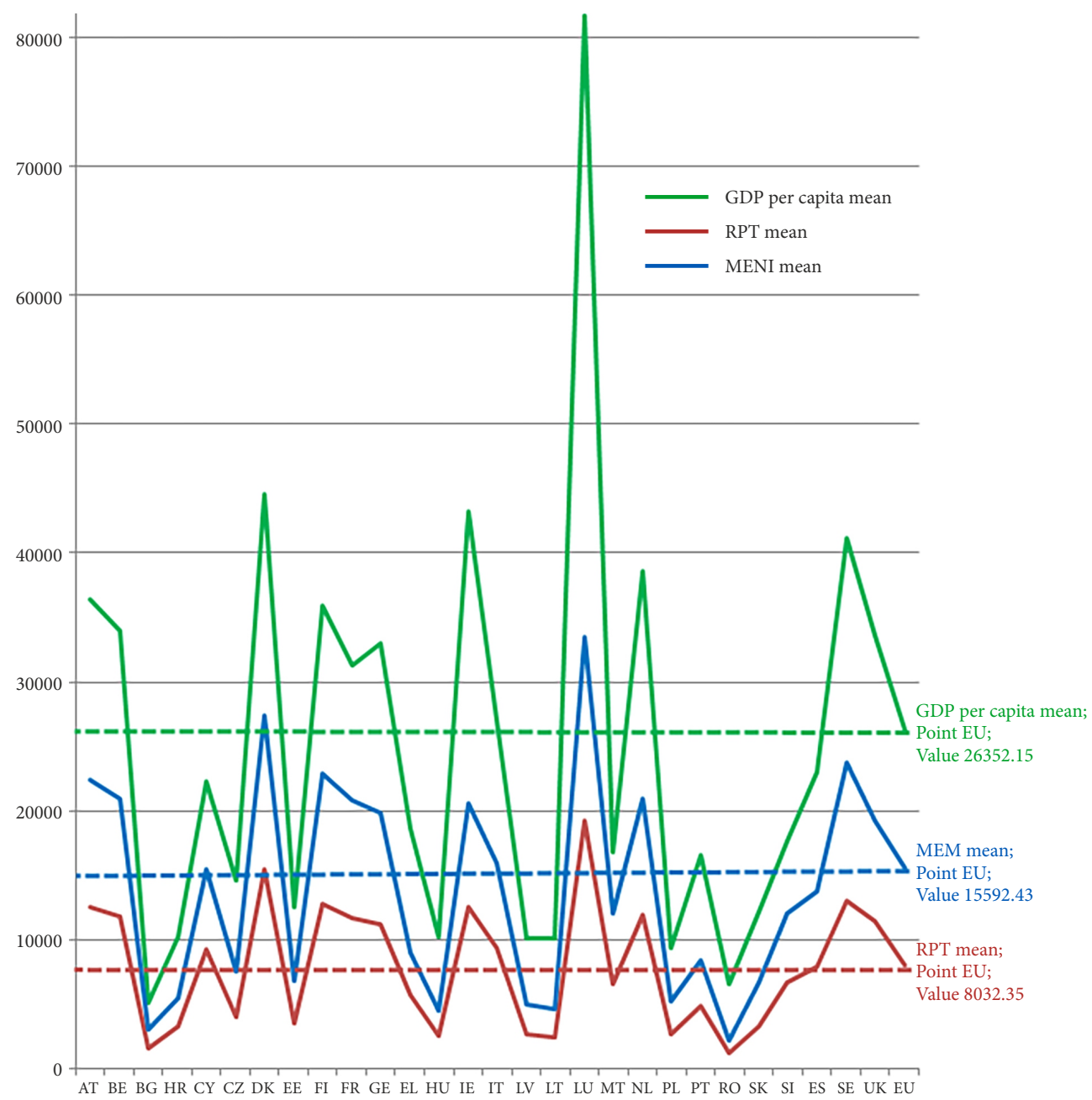

Figure 3. Individual GDP, RPT and MENI mean values over 2005-2016, compared to the EU mean values 
The same holds for the GINI index (Figure 4): 12 countries with mean GINI index above the EU mean, while the others are situated below.

As a result of the analysis for GDP mean values, there is a clear delimitation: 12 states of EU (LU, DK, IE, SE, NL, AT, FI, BE, UK, GE, FR, IT) have a mean GDP above the EU mean value, while the other 16 (ES, CY, EL, SI, MT, PT, CZ, EE, SK, HR, HU, LT, LV, PL, RO, BG) have a mean GDP lower than the EU average. Also, note that for Luxembourg, the mean GDP value is 3 times bigger than the EU mean value, and almost double compared to one of the second placed country, also having a very small population.

As the values for all four indicators are available only for a period span of 12 years (20052016), the information is insufficient to obtain statistically significant results in subsequent processing at individual country level. Thus, we considered appropriate to analyze these indicators at the panel level.

In addition to the all country panel (Panel EU28), in order to ensure a homogeneity in processing, we formed 2 other panels:

- Panel 1, containing 11 countries with mean GDP above the EU mean, excluding Luxembourg for the reason mentioned above;

- Panel 2, containing the bottom 9 countries (CZ, EE, SK, HU, LT, LV, PL, RO, BG), with mean GDP below the EU mean, that are also emerging European countries.

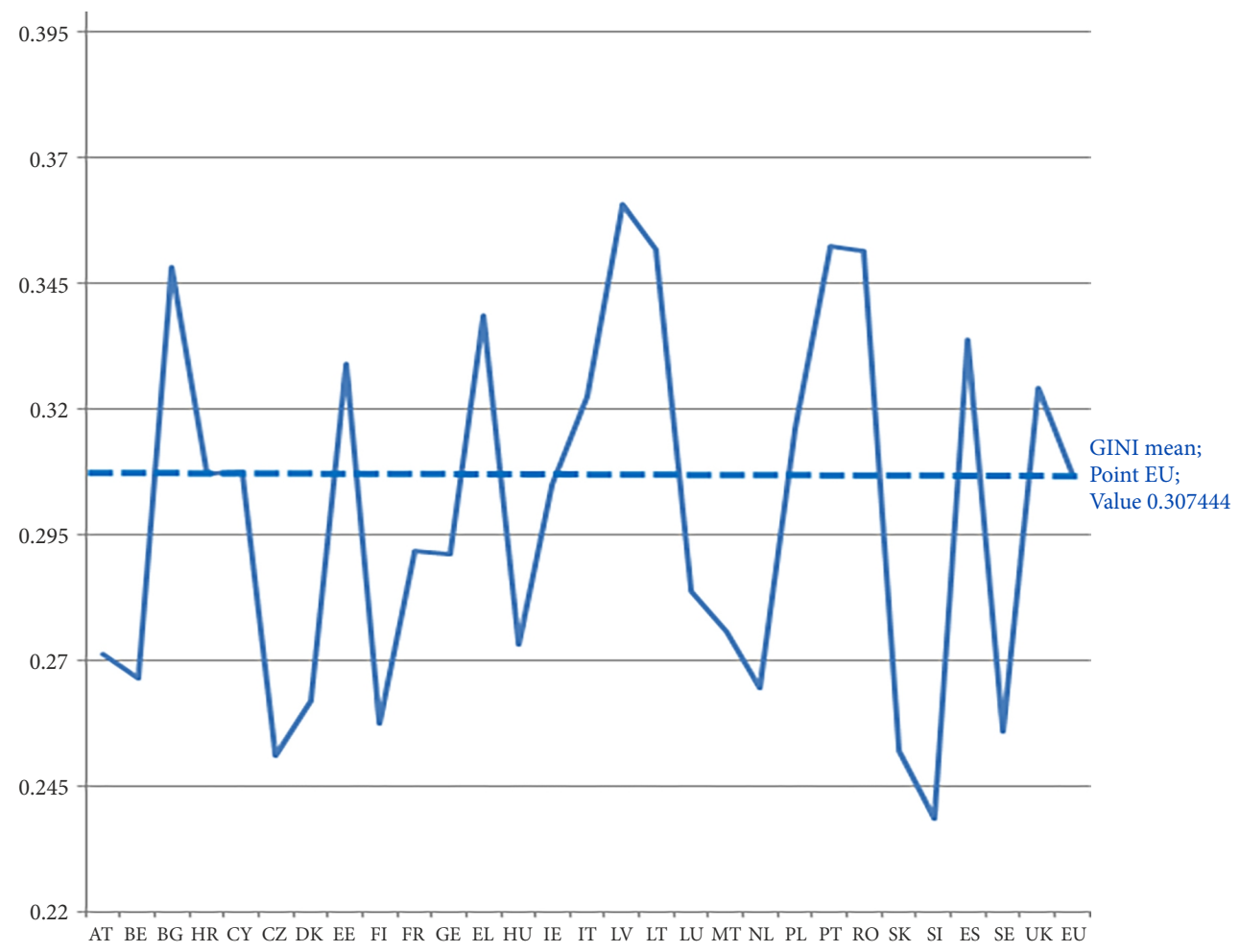

Figure 4. Individual GINI mean values over 2005-2016, compared to the EU mean value 


\subsection{Panel cointegration}

Using EViews 9 software we estimated the two theoretical models. In Table 2, the results show that processes are stationary for at $1 \%$ confidence level, for all variables in panel EU28 or panel 2. For these tests we selected individual effects option and automatic lag selection.

Table 2. Results of the panel unit root tests. Variables GINI, LGDP, LRPT, LMENI

\begin{tabular}{|l|c|c|c|c|c|c|c|}
\hline \multirow{4}{*}{ Variable } & \multicolumn{2}{|c|}{ Levin, Lin \& Chu t* } & \multicolumn{2}{l|}{ ADF - Fisher Chi-square } & \multicolumn{2}{l|}{ PP - Fisher Chi-square } \\
\cline { 3 - 8 } & & Statistic & Prob. & Statistic & Prob. & Statistic & Prob. \\
\hline \multirow{4}{*}{ Panel EU28 } & GINI & -8.57251 & 0.0000 & 108.037 & 0.0000 & 106.713 & 0.0001 \\
\cline { 2 - 8 } & LGDP & -7.66993 & 0.0000 & 100.522 & 0.0002 & 143.067 & 0.0000 \\
\cline { 2 - 8 } & LRPT & -9.75593 & 0.0000 & 110.592 & 0.0000 & 162.014 & 0.0000 \\
\cline { 2 - 8 } & LMENI & -9.75232 & 0.0000 & 110.571 & 0.0000 & 162.022 & 0.0000 \\
\hline \multirow{4}{*}{ Panel 1 } & GINI & -5.13854 & 0.0000 & 37.7951 & 0.0193 & 34.7260 & 0.0414 \\
\cline { 2 - 8 } & LGDP & -3.94143 & 0.0000 & 30.5947 & 0.1047 & 40.7887 & 0.0087 \\
\cline { 2 - 8 } & LRPT & -4.63002 & 0.0000 & 28.0349 & 0.1745 & 38.3751 & 0.0166 \\
\cline { 2 - 8 } & LMENI & -4.62683 & 0.0000 & 28.0193 & 0.1750 & 38.3086 & 0.0169 \\
\hline \multirow{5}{*}{ Panel 2 } & GINI & -7.75138 & 0.0000 & 55.3478 & 0.0000 & 55.9205 & 0.0000 \\
\cline { 2 - 8 } & LGDP & -7.42181 & 0.0000 & 38.6495 & 0.0032 & 76.7448 & 0.0000 \\
\cline { 2 - 8 } & LRPT & -9.47496 & 0.0000 & 58.3112 & 0.0000 & 86.1760 & 0.0000 \\
\cline { 2 - 8 } & LMENI & -9.47433 & 0.0000 & 58.3001 & 0.0000 & 86.2518 & 0.0000 \\
\hline
\end{tabular}

For the first difference processes for the variables in panel 1, the processes are stationary, at $1 \%$ confidence level for all four indicators. After verifying the stationarity, we tested the cointegration. Following the Pedroni test, we found that the variables are cointegrated at a confidence level of $10 \%$, for both models (linear and quadratic), and all panels. Following the Kao test, the results show the existence of cointegration between the studied variables, in the long term.

In Table 3 below we presented the results of the Granger causality test between all pairs of the four variables in this study, using a 2-lags option. Analyzing the results in Table 3 we found:

- no Granger causality for between GINI and the other three variables for all three panels, except for panel 1, where we found an unidirectional Granger causality GINI $\rightarrow$ RPT and GINI $\rightarrow$ MENI;

- bidirectional Granger causality GDP $\leftrightarrow$ RPT and GDP $\leftrightarrow$ MENI for all three panels;

- bidirectional Granger causality RPT $\leftrightarrow$ MENI for the EU28 panel;

- no Granger causality RPT $\leftrightarrow$ MENI for the other two panels.

We may conclude that the values of GDP, RPT or MENI from at most two previous years cannot be used to forecast the current value of the GINI index. At the same time, the current values of MENI and RPT can be influenced by lagged values of GDP.

This justify in a way our approach to estimate GINI using models in which there are not present the other lagged variables. 
Table 3. Granger causality

\begin{tabular}{|l|c|c|c|c|c|c|}
\hline \multirow{2}{*}{ Null Hypothesis: } & \multicolumn{2}{|c|}{ Panel EU28 } & \multicolumn{2}{c|}{ Panel 1} & \multicolumn{2}{c|}{ Panel 2} \\
\cline { 2 - 7 } & F-Statis. & Prob. & F-Statis. & Prob. & F-Statis. & Prob. \\
\hline L_GDP_does not Granger Cause GINI_ & 1.316 & 0,27 & 0.004 & 0.996 & 0.160 & 0.852 \\
\hline GINI_does not Granger Cause L_GDP_ & 0.718 & 0.489 & 0.301 & 0.741 & 0.171 & 0.844 \\
\hline L_RPT_does not Granger Cause GINI_ & 1.966 & 0.142 & 1.148 & 0.321 & 0.550 & 0.579 \\
\hline GINI_does not Granger Cause L_RPT_ & 1.736 & 0.178 & 4.218 & $0.017^{* *}$ & 0.452 & 0.638 \\
\hline L_MENI_does not Granger Cause GINI_ & 1.960 & 0.143 & 1.146 & 0.322 & 0.547 & 0.581 \\
\hline GINI_does not Granger Cause L_MENI_ & 1.732 & 0.179 & 4.221 & $0.017^{* *}$ & 0.450 & 0.640 \\
\hline L_RPT_does not Granger Cause L_GDP_ & 3.499 & $0.032^{* *}$ & 2.350 & $0.010^{*}$ & 2.544 & $0.085^{* * *}$ \\
\hline L_GDP_does not Granger Cause L_RPT_ & 148.609 & $4 . \mathrm{E}-44^{*}$ & 14.689 & $2 . \mathrm{E}-06^{*}$ & 118.801 & $6 . \mathrm{E}-25^{*}$ \\
\hline L_MENI_does not Granger Cause L_GDP_- & 3.493 & $0,032^{* *}$ & 2.347 & $0.100^{* * *}$ & 2.542 & $0.085^{* *}$ \\
\hline L_GDP_does not Granger Cause L_MENI_- & 148.713 & $4 . \mathrm{E}-44^{*}$ & 14.690 & $2 . \mathrm{E}-06^{*}$ & 119.094 & $6 . \mathrm{E}-25^{*}$ \\
\hline L_MENI_does not Granger Cause L_RPT_ & 5.950 & $0.003^{*}$ & 0.616 & 0.542 & 1.926 & 0.152 \\
\hline L_RPT_does not Granger Cause L_MENI_ & 5.860 & $0.003^{*}$ & 0.605 & 0.548 & 1.896 & 0.157 \\
\hline
\end{tabular}

Note: ${ }^{*}$ Denotes that the null hypothesis is rejected at 0.01 level; ${ }^{* *}$ denotes that the null hypothesis is rejected at 0.05 level; ${ }^{* *}$ denotes that the null hypothesis is rejected at 0.1 level. The null hypothesis is accepted for all other values.

For instance, for the linear equation (1), with the explanatory variable RPT, for EU28 panel, we obtained for the Hausman test the probability $\mathrm{P}=0.05$, while for the redundant fixed effects test both $\mathrm{F}$ and Chi-square probabilities equal to 0.0 . So, we chose the fixed effect for data. Similar results were obtained for the other panels.

For the second model, the probabilities for both tests are 0.0 . So, for analyzed data set the most appropriate has been shown to be the fixed effects model.

The values of the estimated parameters for equations (1), (2), are reported in Tables 4 and 5.

The estimations of coefficients in the linear model (1) reported in Table 4, show the same type of results for data in panel EU28 or panel 2, proving that GDP has a positive influence on GINI, while RPT and MENI have a negative influence. This means that the values of the GINI index should increase when LGDP increases, and should decrease when RPT and MENI increase (Figure 5). The results in Table 4, estimating equation (1) for data in panel 1 , show an opposite conclusion. In this case, GDP has a negative influence on GINI, while RPT and MENI have a positive influence (Figure 6).

According to the data in the Table 5, we find that all but one of the critical values, reported also for each estimation, are situated inside the corresponding intervals for the LGDP variable. Those intervals are [3.49,4.77] for EU28 panel, [4.41,4.77] for panel 1, and [3.49,4.23] for panel 2. This means that the turning point is situated inside the data interval (or closed to it).

For EU28 panel, the estimated coefficients in Table 5 show that, assuming fixed values of the $\mathrm{Z}$ variables (RPT, MENI), the graph has a " $U$ "-shaped form for the variation of GINI index with respect to log GDP per capita. 
Table 4. Panel EU28, Panel 1 and Panel 2 results for coefficients estimates of Eq. (1)

\begin{tabular}{|c|c|c|c|c|c|c|}
\hline \multirow[t]{2}{*}{ Variable } & \multicolumn{3}{|c|}{ Equation (1) with RPT } & \multicolumn{3}{|c|}{ Equation (1) with MENI } \\
\hline & Coefficient & Std. Error & Prob. & Coefficient & Std. Error & Prob. \\
\hline \multicolumn{7}{|c|}{ Panel EU28 } \\
\hline $\mathrm{C}$ & 0.290736 & 0.062062 & 0.0000 & 0.294730 & 0.060680 & 0.0000 \\
\hline LGDP & 0.017933 & 0.025611 & 0.4844 & 0.017998 & 0.025613 & 0.4828 \\
\hline LRPT & -0.018230 & 0.018881 & 0.3531 & - & - & - \\
\hline LMENI & - & - & - & -0.018288 & 0.018883 & 0.3336 \\
\hline \multicolumn{7}{|c|}{ Statistic } \\
\hline $\mathrm{R}^{2}$ & 0.900134 & & & 0.900135 & & \\
\hline SER & 0.012847 & & & 0.012847 & & \\
\hline \multicolumn{7}{|c|}{ Panel 1} \\
\hline $\mathrm{C}$ & -0.032219 & 0.108773 & 0.7676 & -0.051816 & 0.109370 & 0.6365 \\
\hline LGDP & -0.009833 & 0.037957 & 0.7960 & -0.009873 & 0.037954 & 0.7952 \\
\hline LRPT & 0.088198 & 0.034133 & 0.0110 & - & - & - \\
\hline LMENI & - & - & - & 0.088247 & 0.034131 & 0.0109 \\
\hline \multicolumn{7}{|l|}{ Statistic } \\
\hline $\mathrm{R}^{2}$ & 0.869395 & & & 0.869404 & & \\
\hline SER & 0.009994 & & & 0.009994 & & \\
\hline \multicolumn{7}{|c|}{ Panel 2} \\
\hline $\mathrm{C}$ & 0.345040 & 0.098067 & 0.0007 & 0.353084 & 0.094578 & 0.0003 \\
\hline LGDP & 0.023738 & 0.044134 & 0.5919 & 0.023890 & 0.044136 & 0.5896 \\
\hline LRPT & -0.037033 & 0.030031 & 0.2206 & - & - & - \\
\hline LMENI & - & - & - & -0.037153 & 0.030036 & 0.2192 \\
\hline \multicolumn{7}{|c|}{ Statistic } \\
\hline $\mathrm{R}^{2}$ & 0.888650 & & & 0.888661 & & \\
\hline SER & 0.015791 & & & 0.015790 & & \\
\hline
\end{tabular}

Note: R-squared - $\mathrm{R}^{2}$; S.E. of regression - SER.

Thus, the values of the GINI index should decrease until LGDP reaches the critical point, followed by an increase after LGDP exceeds the critical value. In addition, both variables RPT and MENI have a negative influence on GINI, i.e. an increase of the values for these variables leads to a decrease of GINI.

According to the estimations of coefficients with data in panel 1, the graph showing the variation of GINI index with respect to LGDP follows a " $U$ "-shaped form when the effect of RPT or MENI is taken into account. This means that the values of the GINI index should decrease until LGDP reaches the critical point, followed by an increase after LGDP exceeds the critical value. In addition, both variables RPT and MENI have a positive influence on GINI, i.e. an increase of the values for these variables leads to an increase of GINI. 
Table 5. Panel EU28, Panel 1 and Panel 2 results for coefficients estimates of Eq. (2)

\begin{tabular}{|c|c|c|c|c|c|c|c|c|c|}
\hline \multirow[t]{2}{*}{ Variable } & \multicolumn{3}{|c|}{$\begin{array}{l}\text { Equation (2) } \\
\text { with RPT }\end{array}$} & \multicolumn{3}{|c|}{$\begin{array}{l}\text { Equation (2) } \\
\text { with MENI }\end{array}$} & \multicolumn{3}{|c|}{$\begin{array}{l}\text { Equation (2) without } \\
\text { RPT and MENI }\end{array}$} \\
\hline & Coefficient & Std. Error & Prob. & Coefficient & Std. Error & Prob. & Coefficient & Std. Error & Prob. \\
\hline \multicolumn{10}{|c|}{ Panel EU28 } \\
\hline $\mathrm{C}$ & 1.108386 & 0.423982 & 0.0094 & 1.109370 & 0.422446 & 0.0091 & 1.157615 & 0.396416 & 0.0038 \\
\hline LGDP & -0.385907 & 0.208734 & 0.0655 & -0.385636 & 0.208724 & 0.0657 & -0.413606 & 0.190919 & 0.0311 \\
\hline $\mathrm{LGDP} \wedge 2$ & 0.047080 & 0.024152 & 0.0522 & 0.047050 & 0.024151 & 0.0523 & 0.049511 & 0.022972 & 0.0319 \\
\hline LRPT & -0.006526 & 0.019728 & 0.7410 & - & - & - & - & - & - \\
\hline LMENI & - & - & - & -0.006593 & 0.019730 & 0.7385 & - & - & - \\
\hline \multicolumn{10}{|c|}{ Statistic } \\
\hline R-squared & 0.901395 & & & 0.901396 & & & 0.901359 & & \\
\hline $\begin{array}{l}\text { S.E. of } \\
\text { regression }\end{array}$ & 0.012787 & & & 0.012787 & & & 0.012768 & & \\
\hline $\begin{array}{l}\text { Critical } \\
\text { value }\end{array}$ & 4.098418 & “U” & & 4.098151 & “U” & & 4.176910 & “U” & \\
\hline \multicolumn{10}{|c|}{ Panel 1} \\
\hline $\mathrm{C}$ & 1.014885 & 4.129848 & 0.8063 & 0.996117 & 4.125535 & 0.8096 & -2.887730 & 3.897167 & 0.4602 \\
\hline LGDP & -0.470228 & 1.815201 & 0.7960 & -0.470985 & 1.815076 & 0.7957 & 1.318335 & 1.700563 & 0.4397 \\
\hline LGDP^2 & 0.049885 & 0.196640 & 0.8002 & 0.049963 & 0.196627 & 0.7999 & -0.136572 & 0.185499 & 0.4630 \\
\hline LRPT & 0.091805 & 0.037099 & 0.0141 & - & - & - & - & - & - \\
\hline LMENI & - & - & - & 0.091859 & 0.037096 & 0.0147 & - & - & - \\
\hline \multicolumn{10}{|c|}{ Statistic } \\
\hline $\mathrm{R}^{2}$ & 0.869467 & & & 0.869475 & & & 0.862693 & & \\
\hline SER & 0.010033 & & & 0.010033 & & & 0.010247 & & \\
\hline $\begin{array}{l}\text { Critical } \\
\text { value }\end{array}$ & 4.713120 & “U” & & 4.713338 & “U” & & $4.82652^{\star}$ & “П” & \\
\hline \multicolumn{10}{|c|}{ Panel 2} \\
\hline $\mathrm{C}$ & -1.854512 & 1.365881 & 0.1778 & -1.845221 & 1.364976 & 01797 & -1.629132 & 1.362295 & 0.2348 \\
\hline LGDP & 1.136935 & 0.690908 & 0.1032 & 1.136889 & 0.690841 & 0.1032 & 1.006763 & 0.687555 & 0.1465 \\
\hline $\mathrm{LGDP}^{\prime} \wedge 2$ & -0.139811 & 0.086600 & 0.1098 & -0.139789 & 0.086593 & 0.1098 & -0.130109 & 0.086714 & 0.1369 \\
\hline LRPT & -0.040973 & 0.029878 & 0.1736 & - & - & - & - & - & - \\
\hline LMENI & - & - & - & -0.041075 & 0.029881 & 0.1726 & - & - & - \\
\hline \multicolumn{10}{|c|}{ Statistic } \\
\hline $\mathrm{R}^{2}$ & 0.891685 & & & 0.891695 & & & 0.889495 & & \\
\hline SER & 0.015657 & & & 0.015657 & & & 0.015731 & & \\
\hline $\begin{array}{l}\text { Critical } \\
\text { value }\end{array}$ & 4.065971 & “П” & & 4.066447 & “П” & & 3.868921 & “ " & \\
\hline
\end{tabular}

Note: ${ }^{\star}$ Denotes that the critical value is situated outside the data interval. R-squared $-\mathrm{R}^{2}$; S.E. of regression - SER.

For data in panel 2, the graph has an inverted U-shaped form in all three cases, meaning that the values of the GINI index should increase until LGDP reaches the critical point, followed by a decrease after LGDP exceeds the critical value. In addition, both variables RPT and MENI have a negative influence on GINI, i.e. an increase of the values for these variables leads to a decrease of GINI. 


\subsection{Discussions}

According to the present research, we can say that the poverty target of the EU 2020 strategy cannot be achieved, as income inequality has increased over the period 2005-2016 in more than half of the EU member states. Generally, although there has been a reduction in income inequality globally, and emerging countries have partially recovered the gap to the wealthy ones, domestic revenue inequality has increased.

Although EU economic growth has been particularly strong (especially for the emerging countries in panel 2), poverty remains a major problem at EU level, being closely linked to income inequality (the highest level of the GINI index, and the lowest poverty threshold). In conclusion, we can say that the relative poverty status does not completely disappear, nor can it be general, but it may take more pronounced or attenuated forms.

Our calculations show although a very large drop in income inequality (GINI) would be necessary to achieve the poverty target from Europe 2020 strategy, this reduction is unlikely to happen given the low historical variations in income inequality and the lack of strong policy reducing income inequality.

Comparisons with the situation across the European Union show that the relative distance between the disposable income in panel 2 and the poverty line was much higher than the EU average. At the same time, we found that economic growth had a uniform impact on states in terms of the poverty line and average income equivalent.

The influence on the income inequality of the three considered indicators is either positive or negative, and the effect depends on the panel (as in Inyong, 2012). A positive influence on income inequality means an increase of GINI, while a negative influence means a decrease of GINI.

Using the linear model (1) we found the same type of influence of GDP, RPT, and MENI on income inequality GINI, for both EU28 panel and panel 2, consisting in emerging European countries (as in Luan \& Zhou, 2017). According to this model, a decrease on income inequality can be obtained by increasing RPT or MENI, while increasing income inequality is affected by GDP growth (as in Chemli \& Smida, 2013).

A similar conclusion can be deduced about the emerging countries in panel 2 using the quadratic model (2). Thus, this model also proves a negative influence of MENI and RPT on income inequality. In addition, the inverted U-shaped for the dependence on GDP implies that the income inequality increases when GDP increases until it reaches a critical value, then the income inequality decreases when GDP exceeds the critical value (Figure 5). These results are similar to those in Grijalva (2011).

For the data in panel 1, containing highly developed European countries, we obtained an opposite behavior compared to one of the emerging countries in panel 2. Thus, according to the linear model (1), an increasing GDP leads to a decrease of income inequality, while RPT and MENI have a direct influence on income inequality. Using the quadratic model (2) we obtained similar conclusion. Thus, we obtained a positive influence of RPT and MENI on income inequality, and a U-shaped form for the dependence on GDP. Let us mention that the critical value of GDP obtained in this case is closed to the right side of the interval, meaning that the influence of GDP on income inequality is mostly negative (Figure 6). 
a)

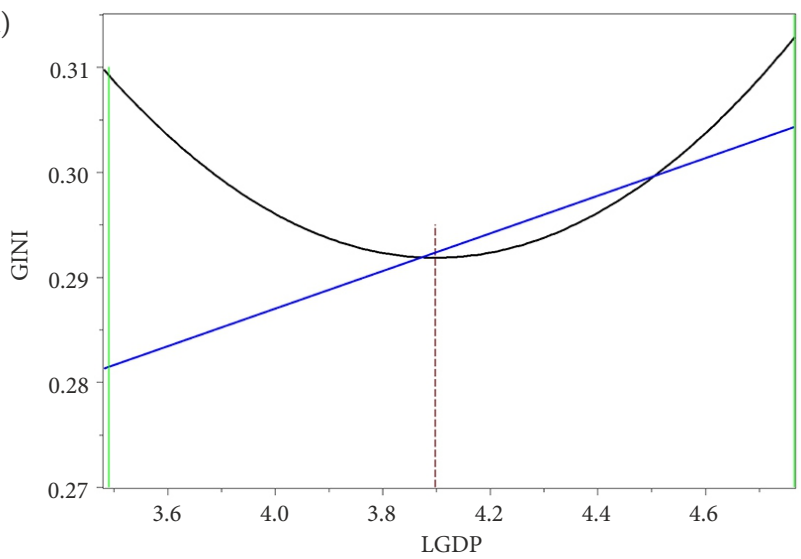

b)

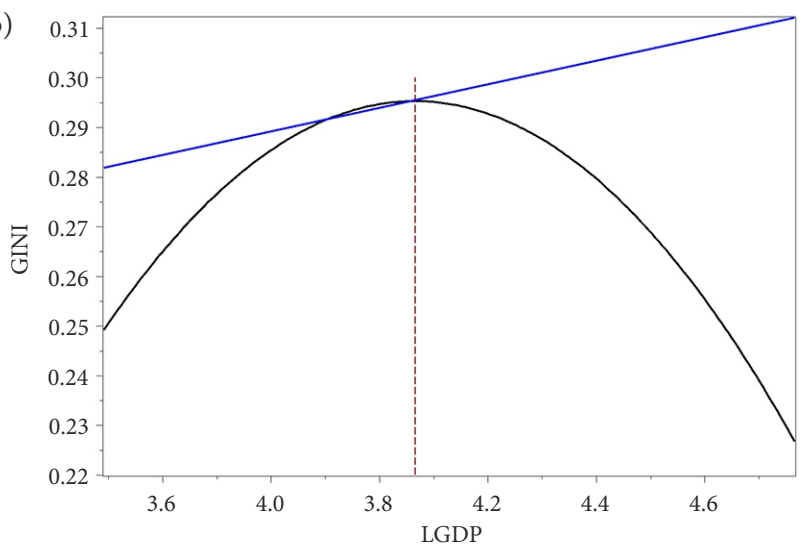

Figure 5. Dependence of GINI on LGDP, linear model and quadratic model, fixed RPT, for: a) EU28 Panel (to the left); b) Panel 2 (to the right)

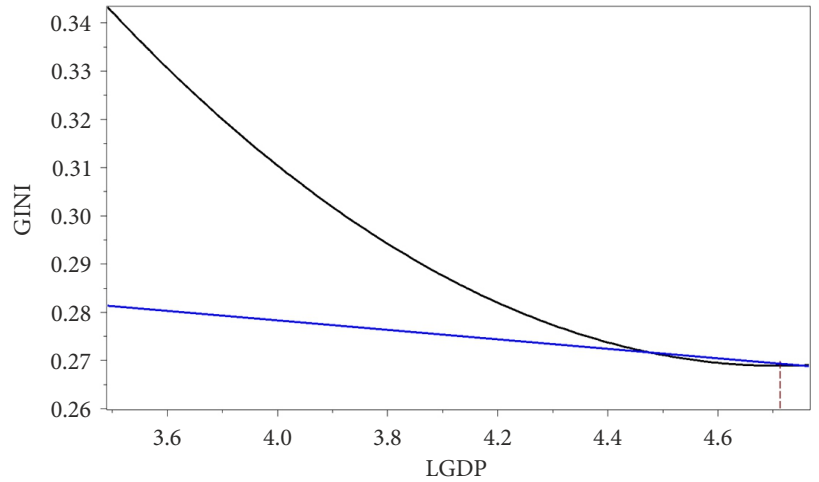

Figure 6. Dependence of GINI on LGDP, linear model and quadratic model, fixed RPT, for Panel 1 


\section{Conclusions}

We may conclude that the poverty target of the EU 2020 strategy cannot be achieved. Although a very large drop in income inequality would be necessary to achieve the target, this reduction is unlikely to happen given the low historical variations in income inequality and the lack of strong policy reducing income inequality.

The linear model (1) proves that at EU level, the three macroeconomic indicators, GDP, RPT, and MENI, have the same type of influence on income inequality as for the emerging countries in panel 2 (namely positive, negative, and negative, respectively), while for the highly developed countries in panel 1 the influences are opposite.

Using the quadratic model (2), we obtained for the EU28 panel the same influence of GDP on income inequality as for panel 1, while the influence of MENI and RPT on income inequality is the same as for panel 2 .

Consequently, the results in our study confirm the Kuznets hypothesis that income inequality tends to increase with early economic development and tends to decrease when a country reaches a certain level of development.

The conclusion of this study concerning the influence of the indicators (per capita gross product domestic, risk of poverty threshold, and median equivalized net income) on income inequality, may be summarized as follows: for the emerging EU countries, increasing risk of poverty threshold or median equivalized net income tends to diminish the income inequality, while economic growth results to increase income inequality; for highly developed EU countries, increasing risk of poverty threshold or median equivalized net income leads to increase income inequality, while economic growth leads to a decrease in income inequality. At the same time, at EU level, the influence of gross domestic product on income inequality is strongly determined by its trend in the highly developed EU countries, while the influence of risk of poverty threshold and median equivalized net income on income inequality is strongly determined by their trend in the emerging EU countries.

As a policy implication, in agreement to the Europe 2020 strategy, in order to reduce income inequality for the emerging countries with economic growth, an increase of risk of poverty threshold or median equivalized net income could be useful.

\section{Author contributions}

All three authors contributed equally to this work.

\section{Disclosure statement}

Authors have no conflicts of interest to disclose. 


\section{References}

Baiardi, D., \& Morana, C. (2016). The financial Kuznets curve: Evidence for the euro area. Journal of Empirical Finance, 39, 265-269. https://doi.org/10.1016/j.jempfin.2016.08.003

Baiardi, D., \& Morana, C. (2018). Financial development and income distribution inequality in the euro area. Economic Modelling, 70, 40-55. https://doi.org/10.1016/j.econmod.2017.10.008

Ben Amar, M., \& Zghidi, N. (2016). The relationship between inclusive growth, inequality and poverty in Africa. Theoretical and Applied Economics, XXIII, 1(606), 117-126.

Binatli, A. O. (2012). Growth and income inequality: A comparative analysis. Economics Research International, Article ID 569890. https://doi.org/10.1155/2012/569890

Bourguignon, F. (2003, November 13). The poverty-growth-inequality triangle. Paper presented at the Conference on poverty, inequality and growth, Paris, France.

Brady, D., \& Jäntti, M. (2017). Economic performance, poverty, and inequality in rich countries. In D. Brady, \& L. M. Burton (Eds.), The Oxford handbook of the social science of poverty. https://doi.org/10.1093/oxfordhb/9780199914050.001.0001

Brueckner, M., Dabla Norris E., \& Gradstein, M. (2015). National income and its distribution. Journal of Economic Growth, 20(2), 149-175. https://doi.org/10.1007/s10887-015-9113-4

Ceriani, L., \& Verme, P. (2012). The origins of the Gini index: extracts from Variabilità e Mutabilità (1912) by Corrado Gini. The Journal of Economic Inequality, 10(3), 421-443. https://doi.org/10.1007/s10888-011-9188-x

Chambers, D., \& Dhongde, S. (2016). Convergence in income distributions: Evidence from a panel of countries. Economic Modelling, 59, 262-270. https://doi.org/10.1016/j.econmod.2016.07.019

Chang, S., Gupta, R., \& Miller, S. M. (2018). Causality between per capita real GDP and income inequality in the U.S.: Evidence from a wavelet analysis. Social Indicators Research, 135(1), 269-289. https://doi.org/10.1007/s11205-017-1792-0

Chemli, L., \& Smida, M. (2013). Interaction between poverty, growth, and inequality during the crisis: A panel data study. International Journal of Economics and Finance, 5(5), 120-130. https://doi.org/10.5539/ijef.v5n5p120

Choi, I. (2001). Unit root tests for panel data. Journal of International Money and Finance, 20, 249-272. https://doi.org/10.1016/S0261-5606(00)00048-6

Cingano, F. (2014). Trends in income inequality and its impact on economic growth (OECD Social, Employment and Migration Working Papers No. 163). Paris: OECD Publishing. https://doi.org/10.1787/5jxrjncwxv6j-en

Darvas, Z. (2019). Why is it so hard to reach the EU's poverty target? Social Indicators Research, 141(3), 1081-1105. https://doi.org/10.1007/s11205-018-1872-9

Edward, P., \& Sumner, A. (2018). Global poverty and inequality: are the revised estimates open to an alternative interpretation? Third World Quarterly, 39(3), 487-509. https://doi.org/10.1080/01436597.2017.1401461

Engle, G., \& Granger, C. (1987). Co-integration and error correction: Representation, estimation, and testing. Econometrica, 55(2), 251-276. https://doi.org/10.2307/1913236

European Anti-Poverty Network. (2016). Letter sent to President of the European Commission Mr JeanClaude Juncker about the Annual Growth Survey 2017. Retrieved from http://www.eapn.eu/wpcontent/uploads/2016/10/EAPN-2017-EAPN-letter-Juncker-AGS2017-630.pdf

European Commission. (2017). Europe 2020 strategy. Retrieved from https://ec.europa.eu/info/business-economy-euro/economic-and-fiscal-policy-coordination/eu-economic-governance-monitoring-prevention-correction/european-semester/framework/europe-2020-strategy_en 
European Union. (2013). Regulation (EU) No 1304/2013 of the European Parliament and of the Council on the European Social Fund and Repealing Council Regulation (EC) No 1081/2006. Retrieved from http://data.europa.eu/eli/reg/2013/1304/oj

EViews 9. (2015). User's Guide I, II. IHS Global Inc. Retrieved from www.eviews.com

Fosu, A. K. (2017). Growth, inequality and poverty reduction in developing countries: recent global evidence. Research in Economics, 71(2), 306-336. https://doi.org/10.1016/j.rie.2016.05.005

Grijalva, D. F. (2011). Inequality and economic growth: Bridging the short-run and the long-run. University of California, Irvine. Retrieved from http://www.democracy.uci.edu/files/democracy/docs/ conferences/grad/2011/Diego\%20-\%20Inequality\%20and\%20growth\%20CSD.pdf

Halmos, K. (2011). The effect of FDI, exports and GDP on income inequality in 15 Eastern European countries. Acta Polytechnica Hungarica, 8(1), 123-136.

Hillebrand, E. (2009). Poverty, growth, and inequality over the next 50 years. Paper presented at the Expert Meeting on How to Feed the World in 2050, Food and Agriculture Organization of the United Nations Economic and Social Development Department.

Inyong, S. (2012). Income inequality and economic growth. Economic Modelling, 29(5), 2049-2057. https://doi.org/10.1016/j.econmod.2012.02.011

Jauch, S., \& Watzka, S. (2016). Financial development and income inequality: a panel data approach. Empirical Economics, 51(1), 291-314. https://doi.org/10.1007/s00181-015-1008-x

Kao, C. (1990). Spurious regression and residual-based tests for cointegration in panel data. Journal of Economics, 90, 1-44. https://doi.org/10.1016/S0304-4076(98)00023-2

Kuznets, S. (1955). Economic growth and income inequality. The American Economic Review, 45(1), $1-28$.

Laurinavičius, A., \& Galinienè, B. (2013). Asset-based approach to poverty reduction in Lithuania. Technological and Economic Development of Economy, 19(2), 203-223. https://doi.org/10.3846/20294913.2013.796609

Levin, M., Lin, C. F., \& Chu, C. S. (2002). Unit root tests in panel data: asymptotic and finite sample properties. Journal of Economics, 108, 1-24. https://doi.org/10.1016/S0304-4076(01)00098-7

Luan, Z., \& Zhou, Z. (2017). The relationship between annual GDP growth and income inequality: Developed and undeveloped countries. Econ, 3161, 1-16. Retrieved from https://smartech.gatech. edu/bitstream/handle/1853/56630/paper-2.docx.pdf

Mihi-Ramírez, A., Kumpikaitè-Valiūnienė, V., \& Cuenca-García, E. (2017). An inclusive analysis of determinants of international migration. The case of European rich and poor countries. Technological and Economic Development of Economy, 23(4), 608-626. https://doi.org/10.3846/20294913.2017.1306726

OECD. (2014). Correlation between Gini coefficients and GDP per capita, 1820-2000. https://doi.org/10.1787/9789264214262-graph88-en

Pedroni, P. (1999). Critical values for cointegration tests in heterogeneous panels with multiple regressors. Oxford Bulletin of Economics and Statistics, 61, 653-673. https://doi.org/10.1111/1468-0084.61.s1.14

Rubin, A., \& Segal, D. (2015). The effects of economic growth on income inequality in the US. Journal of Macroeconomics, 45, 258-273. https://doi.org/10.1016/j.jmacro.2015.05.007

Škare, M., \& Pržiklas Družeta, R. (2016). Poverty and economic growth: a review. Technological and Economic Development of Economy, 22(1), 156-175. https://doi.org/10.3846/20294913.2015.1125965

Soava, G., Mehedintu, A., Sterpu, M., \& Raduteanu, M. (2018). Impact of renewable energy consumption on economic growth: evidence from European Union countries. Technological and Economic Development of Economy, 24(3), 1197-1215. https://doi.org/10.3846/tede.2018.1426 
Strielkowski, W., \& Höschle, F. (2016). Evidence for economic convergence in the EU: the analysis of past EU enlargements. Technological and Economic Development of Economy, 22(4), 617-630. https://doi.org/10.3846/20294913.2014.890138

World Bank. (2001). World development report 2000/2001: Attacking poverty. New York: Oxford University Press. Retrieved from http://hdl.handle.net/10986/11856

Zagorski, K., Evans, M. D. R., Kelley, J., \& Piotrowska, K. (2014). Does national income inequality affect individuals'quality of life in Europe? Inequality, happiness, finances, and health. Social Indicators Research, 117(3), 1089-1110. https://doi.org/10.1007/s11205-013-0390-z 